\title{
Effects of Seasonal Variation Driven Price Disparity on Fresh Flower Business: Evidences from Bangladesh
}

\author{
Shamsun Nahar Momotaz \\ Department of Marketing, School of Business \\ Independent University, Bangladesh \\ Susmita Banik \\ Department of Economics, Stamford University Bangladesh
}

\begin{abstract}
Keywords
Flower business, Channel members, Seasonal variation, Profitability.
\end{abstract}

\begin{abstract}
As an emerging sector, the commercial cultivation of flowers is gaining popularity in Bangladesh and creating a new competition of high-quality flower production. This paper examines the price differences practiced by growers and other channel members of the industry which is affected by seasonal variation. Using the evidence collected from 220 respondents of growers and channel members like local traders, wholesalers and retailers, the study finds that the market price of flowers usually remains uncertain and unstable in Bangladesh, and it is mainly associated with its demand and supply in the market during different seasons. Higher price is observed for Rose, Tuberose, Gerbera, and Gladiolus in rainy season when the supply and wastage of perishable flowers fail to match the demand of those flowers. On the contrary lower price is observed in spring when the supply of flowers increases due to favorable weather for production. However, flower traders get more prices by selling Marigold in winter, the time which is suitable for cultivating and harvesting. Nevertheless, they obtain lower price in summer. Moreover, they receive elevated price in winter for trading Jasmine and poorer in rainy season. This overall market price difference, in turn, affects the profit of the traders. In favorable weather, profits of flowers are found lower due to the additional supply of flowers compared to the demand whereas in adverse weather, extra cost of wastage or post-harvest loss makes the profit lesser again.

This study aims to provide useful policy insights to the policy makers as well as researchers for reducing the seasonal effects on flower trading in Bangladesh. In this way this study will also help the government to realize the importance and develop ways of solving the effects of seasonal variation driven price disparity on fresh flower business.
\end{abstract}

Corresponding author: Shamsun Nahar Momotaz

Email addresses for the corresponding author: snm@iub.edu.bd

First submission received: $6^{\text {th }}$ January 2020

Revised submission received: $1^{\text {st }}$ March 2020

Accepted: 23rd March 2020

\section{Introduction}

In Bangladesh flower cultivation has emerged as a worthwhile business ensuring higher potential to earn money. Demand for flowers is increasing in domestic as well as in international market which is worth of \$16.58 million, and different countries including India, Pakistan, Italy, Portugal, Saudi Arabia, the United States of America, South Korea, the Philippines, Singapore, Japan, Germany, Britain, Denmark and France constitute the international market. The country's export earnings from flower and foliage for FY 2018-19 touched \$3.98 million, up from just \$0.02 million in FY 2017-18 (Export Promotion Bureau, 2018). Besides, according to Dhaka Chamber of Commerce and Industry the country's local market for flowers and cut foliage has reached $\$ 14.12^{1}$ million per annum and growing at 10 per cent per annum (DhakaTribune, 2019). The employment generation for both men and women are rising under floriculture industry at about $15.79 \%$ every year (Rakibuzzaman et al., 2018). Furthermore, around 200,000 people are directly and indirectly depending on this sector and more than 25,000 families are engaged in cultivating fresh flowers 1. $\$ 1=83.20$ Taka by Bangladesh bank, (2019) 
(Hossain, 2019). In 2016-17 the total flower area, yield and production of flowers have been increased to 23000 tons of flowers in total land of 3000 acres from where per acre yield (kg) was 767 (Bangladesh Bureau of Statistics, 2018). The annual turnover of the country's flower and foliage industry increased to BDT 15 billion in FY 2018 from about 2.0 billion a decade back (Labony et al., 2019).

Though the flower business is extended throughout the country, but this still is not enough to meet the market demand. To satisfy the market demand, Bangladesh requires importing flower and ornamental plants costing up to BDT 2-3 million from abroad (Rakibuzzaman, 2018). Among the locally produced flowers being traded regularly in commercial scale, the following are common: different varieties of Rose (Rosa), Gladiolus (Gladiolus), Marigold (Tagates), Tuberose (tuberosa), Gerbera (gerbera jamesonii), Jasmine (Jasminum), Dolanchampa (Hedychium coronarium), Lotus (Nelambo nucifera), Orchid, and Chrysanthemum (Chrysanthemum coronarium). Although major production areas are concentrated in the rural area and the consumption is concentrated in the cities, the success of commercial flower business depends largely on well-developed distribution system as flowers are perishable in nature requiring careful handling and quick marketing. By developing sophisticated distribution system Netherlands became the largest supplier (59 percent) of flowers in the international flower market (Griffin, 1995). But in Bangladesh marketing and distribution of flowers is not organized. The marketing channel of flower business in the country operates through some middlemen like local traders, wholesalers, and retailers to the final consumers. Farmers and channel members are found deprived of getting expected profit due to the price difference occurring in different seasons of the year. In addition, no marketing policy on flowers business has been developed in Bangladesh yet. As the demand in the market is increasing day by day, there exists a threat of competition for producing high quality flowers. Considering the potentiality and growing demands for flowers, there is an urgent need for generation of information of price difference of flowers as affected by seasonal variation in Bangladesh.

However, no systematic study has so far been found to explore the effects of seasonal price differences on flowers business in Bangladesh. The focus on growers' and channel members' perspectives will provide a better insight with respect to the effects of price difference in the flower business of the country. Investigating this topic would provide both the academics and practitioners ideas about expanding flower trading in the country and taking actions to satisfy local demand further as well as advancing the business in international market. The present research study is focused on how various actors are related to the flower business from production to selling process. This study has tried to utilize the accumulated information gathered from 220 respondents of growers and channel members of Savar, and Dhaka metropolitan area to measure the effects of season on price disparity practiced by the channel members for trading fresh flowers. Additionally, the research examines the effects of different season on profitability for flower business. In this way, the study aims to help flower traders to analyze and understand the effects of seasonal variation driven price and profitability disparity in the country. The information will be beneficial to understand the present situation of flower marketing system in Bangladesh. Since the number of flower growers and traders are rising rapidly in the country and more traders are also feeling interested to this industry following research questions are coming up which were not addressed by the past studies:

1. Which types of marketing channels are prevalent in the fresh flower industry in Bangladesh?

2 How much price difference is practiced by the different channel members?

3. How profitability differs with different channels members during different seasons of the year?

4. What are the effects of seasonal variation driven price differentials on the trading pattern of fresh flower business in Bangladesh?

To answer the questions, the objectives of this study have been stated below-

1. To examine the fresh flower channel system in Bangladesh,

2. To estimate the price differences practiced by growers and other channel members during different seasons, and

3. To explore the effects of seasonal disparity driven price disparity on profitability of fresh flower business in Bangladesh.

Answering the research question will help in developing pertinent policy recommendations focusing on identifying the ways to manage the effects of seasonal difference on price and profitability of 
fresh flower trading in Bangladesh. This paper is organized in six sections: the first section presents Introduction; the second section deals with Literature Review. Thereafter, the third section contains Methodology. Findings are provided in section four; Discussions and Conclusion are in section five, and Limitations and Direction for future Research in section six.

\section{Literature Review}

Due to high market potentiality of flower business in Bangladesh, many researchers explored the practice of production, marketing system, and post-harvest loss of flower business in their studies. Mohiuddin (2016) indentified floriculture as a cash cow crops for the farmers and found the good potentials in the production of cut flowers in the country due to favorable environment and fertile land. According to him, flowers as business item came being into the market of Bangladesh before 1983 and over the years, this flower business has taken a good shape in domestic market (2016). From the study of Khan et al. (2017) it is found that the flower business is increasing in developing countries such as Pakistan, Bangladesh and India mainly for the escalating pressure on flower cultivation and that the cut flowers occupied a significant place in the life of human beings due to their involvement in social, cultural and religious activities. According to Labony et al. (2019), the rising income of middle-class people along with rapid socioeconomic development as well as introduction of modern technology, supply of quality seeds, and setting up of some warehouses and cold storages have largely helped raising the flower production. She also showed that flower production surpassed 3.2 billion pieces in FY 2018 from 3.0 billion in FY 2017 and 2.98 billion in FY 2016 (2019). Moreover, Yeasmin (2009) observed a remarkable positive impact of commercial floriculture on increasing the total household income by sharing 0-24.47 percent of the total household income, which is also supported in a study by Omar, et.al, (2014). According to Rakibuzzaman et al (2018), flower demand is increasing day by day simultaneously with the land under flower cultivation and the total yield of flower is also increasing. Among the fresh flower species and their market share, in the FY 2013-14, rose contributes the maximum and the cultivation of rose occupied an area of 281 acres increasing from 189 acres in FY 2013-14. He also found, Gladiolus coming into play in recent times occupied the top position with market share of $31.11 \%$ with the highest level of return followed by Gerbera and Rose (2018).

But Stable price and profit are crucial for growing long-term relationships with customers and in sustaining profitability of flower traders. However due to the relative novelty of the sector, few studies have examined the flower trading and distribution practices among traders and profitability of flower production in Bangladesh. Few researchers have considered profitability or net return from fresh flower business in Bangladesh. For example, Jahan (2009) explored the highest net return from selling rose followed by tuberose, gladiolus, and marigold and found net margin to be the highest with retailers and lowest with wholesalers; Mou (2012) compared the profit and production of some selected flowers with other competing crops and explored higher margin in flower (BDT 1,359,824.20 per ha) than vegetables (BDT 46,362.14 per ha) and discovered that the marketing margin of wholesaler-cum-retailer is higher than retailer. Haque et al. (2012) in their article pointed out the net return from flower cultivation are $81 \%$ higher than lentil, $85 \%$ higher than mustard and $6 \%$ lower than potato cultivation. The benefit-cost ratios are 2.57 and 1.80 on variable cost and full cost basis (2012).

A small number of researchers have considered various factors influencing marketing efficiency in fresh flower business in Bangladesh. Omar et al. (2014) found the Marketing Efficiency and Producer's share in Consumer's Price to be higher for Rose (White), Marigold, Jasmine (Yellow) and Tulip (Purple) before excluding post-harvest loss. On the contrary, price spread for Rose (White), Marigold, Jasmine (Yellow) and Tulip (Purple) is higher after excluding post-harvest loss. They also explored the highest post-harvest losses at the retail level (39.82\%) followed by wholesaler $(27.52 \%)$, producer $(18.87 \%)$ and local trader (13.78\%) in Jessore and Dhaka city of Bangladesh (2014). Begum (2015) found in her study that, the marketing cost (BDT per 100 Flower) is found highest for Gerbera followed by Gladiolus, Marigold and Rose.

However, few studies have examined the price difference practice and the causes behind the price discrimination of flower trading in Bangladesh. Hossain et al. (2015) found the price of different flowers as varied in different days, different months and different special days of the year and the cost of production varies in different kinds of flower. This is also evidenced in the study of Begum (2015) that, though 
everyday sale of flowers is nearly BDT 35-40 lakhs on average in the whole country, but during the eves of different festivals, the amount climbs too high. According to Financial Express (2019), daily sales by flower traders across the country are worth BDT 20,000-Tk 25,000 during normal days but are expected to be the highest in February which is considered as the peak business season. Customers place orders for rose, gladiolas, hyacinth and lily on the occasion of Valentine's Day; for gerbera, daisy, calendula, crecenthimum, small marigold and others in Pohela Falgun (spring festival) and Marigold and tuberose for celebrating Ekushey February (International Mother Language Day). Therefore, in FY 2019 traders expected sales surpass of BDT 0.25 million per day in February due to favorable weather and stable political environment (2019).

Many researchers in India identified important marketing channels for different flower namely Sangeetha (2005) for Aunthurium; Sing et al. (2008) for Marigold; Haridas (2010) for Anthurium; Steephan (2011) for Orchid; Singh \& Pumitha (2012) for Anthurium and Mohanan (2015) for Orchid. As we know that, marketing channels are made of a set of interdependent organizations involved in the process of making a product or service available for use or consumption (Kotler \& Keller, 2014), but only a few researchers explained marketing channels of flower business in Bangladesh. Raha \& Sultana (1995) investigated in their study of different channels of flowers with reference to Dhaka market, where the Channel members are Growers, Bepari, Sarder, Retailer cum Wholesaler, Farmer cum Bepari, and Retailer. Laboni et al. (2019) also examined the supply chain of flower market and the opportunities, challenges and constraints in production and marketing of flower industry in Bangladesh. The paper revealed that the participants of the supply chain of flower business are farmers/growers, wholesalers, wholesalers cum retailers, farmers cum wholesalers cum retailers, stockiest and customers. According to them, various factors that are hindering local production and marketing such as weak research activities, unorganized market, lack of post-harvest management, dependency on import, poor knowledge of farmers, underdeveloped machineries, lack of cold value chain and air-conditioned vehicles, lack of promotion, high air freight, no permanent market, limited government's initiative etc. (2019).

This study attempts to depict the marketing channel practice as well as assess the effects of seasonal price differentials on flowers business in Bangladesh. By searching the literature, a striking imbalance is found where relative or little attention has given to identify the effects of seasonal variation driven price and profit disparity in Bangladesh. As we noticed the flower business as one of the growing industries in Bangladesh, it is important to the growers and other channel members of the industry to realize the effects of seasonal variation on price and profitability. Lastly, the research tries to help in developing significant policy recommendations focusing on identifying the ways to manage the effects of price disparity on flower trading in different seasons to uphold customer satisfaction. In this context, the present study is an endeavor to fill the above-mentioned gaps and analyze the prevailing seasonally varied price and profit differentials of flower business of Bangladesh.

\section{The Methodology}

\subsection{Research Design}

This is a descriptive research where primary data have been gathered by field survey method using a questionnaire, apart from the use of secondary sources of information. For a better understanding of the research problems, and to explore literature, secondary data were collected from different sources for instance articles, books, newsletters, annual reports, government reports, newspapers, websites etc. Indepth interview sessions were conducted involving 5 flower growers and traders in savar. They were selected based on good knowledge and experiences with trading flowers like rose, tuberose, marigold, gerbera, gladiolus, and jasmine in Bangladesh. Information gathered from them helped the researchers to understand the price and profit disparity in different seasons of the year. After refining, categorizing and comparing the information with relevant theoretical and empirical evidence, the content of the survey questionnaires for pilot survey has been developed. Moreover, personal interviews with 20 respondents ( 5 growers, 5 local traders, 5 wholesalers and 5 retailers) were conducted to finalize the questionnaire format, wording and to address any comments or suggestions they had. Then the responses obtained from the pre-test were coded and analyzed. In this way the final questionnaire was designed with closeended and open-ended questions for survey. However, to analyze the seasonal variation driven price and profit disparity in flower business, four seasons were considered namely winter (November to January); 
spring (February to April); summer (May to July) and rainy season (August to October). Data collected from different respondents were analyzed and presented using statistical tools like table, graphs, and charts to illustrate the whole picture of analysis.

\subsection{Sampling Method}

To fulfill the objectives of the study, Convenience sampling technique has been applied for collecting data from 220 samples which include 65 farmers, 47 local traders, 53 wholesalers, and 55 retailers in Manikganj, Birulia, Shyampur, Katlapur of Savar, and Dhaka metropolitan area. Traders having more than five years of experience and actively involved in commercial flower production and marketing were selected for the study. Dhaka Division is considered for the field survey as it is one of the leading flowers producing zones in the country. In addition, Dhaka metropolitan city was selected as the consuming center because $45 \%$ of retail flower shops are located in Dhaka district while Chittagong and Sylhet having $25 \%$ each and the remaining $10 \%$ of shops are situated in other district towns (Labony, 2019). Respondents were personally interviewed by using structured and pretested questionnaire about their socio-economic background, marketing channels, marketing costs, price and profits in the business of selected flowers. The survey was conducted during May to September in the year of 2019.

\subsection{Data Analysis}

This study used the tabular technique to illustrate the whole picture of analysis. To describe the socio-economic characteristics of respondents, descriptive statistics like frequencies, mean etc. was used as a supplement to the tabular technique. The data gathered from the survey were analyzed with the software Microsoft Excel and SPSS 22.

\section{Findings}

\subsection{Results}

\subsubsection{Demographic Profile of Traders}

The age group, gender, education status, family members, family farm workers and total farm workers of the flower growers, local traders, wholesaler and retailers have been presented in table 1 where the sample was made up of mostly male respondents $(99.5 \%)$ except one female grower $(0.5 \%)$. The table also shows that highest representatives of the growers $(23.5 \%)$ are from the age group of above 50 years followed by $40-44$ years $(21 \%)$ and $35-39$ years $(20.5 \%)$. However, most of the local traders $(25.5 \%)$ are from the age group of 35-39 years, wholesalers (22\%) are from $40-44$ years and retailers (22.5\%) from 25-29 years. The study reveals that the flower trading business has attracted mainly the middle-aged people who are usually energetic and responsive to improved farming and possess risk taking ability. The findings also observed many of the growers being literate. The findings also indicate that comparatively literate young people are also involved in trading flowers in Bangladesh. Furthermore, literate youths (44.5\% with education below SSC) are found more interested in fresh flower industry. Besides, majority $(40 \%)$ of the local traders has the primary level of education but majority of the wholesalers $(40 \%)$ and retailers $(25 \%)$ have secondary to above secondary level of education. Thus, it is observed from the study that, they are capable of adopting improved production technology in flower cultivation.

Demographic Variables

1. Age group (in percent)

2. Gender (in percent)

$\begin{array}{lllll}\text { Categories } & \text { Grower } & \text { Local Trader } & \text { Wholesaler } & \text { Retailer } \\ \text { 15-19 years } & 0 & .5 & .5 & .5 \\ \text { 20-24 years } & 0 & 1.0 & 2.5 & 13.5 \\ \text { 25-29 years } & 4.5 & 3.0 & 11.5 & 22.5 \\ \text { 30-34 years } & 18.5 & 14.0 & 20.0 & 17.5 \\ \text { 35-39 years } & 20.5 & 25.5 & 21.0 & 19.5 \\ \text { 40-44 years } & 21.0 & 24.0 & 22.0 & 13.5 \\ \text { 45-49 years } & 12.0 & 13.0 & 12.5 & 7.5 \\ \text { 50 and above years } & 23.5 & 19.0 & 10.0 & 5.5 \\ & & & & \\ \text { Male(percent) } & 99.5 & 100.0 & 100.0 & 100.0 \\ \text { Female } & .5 & 0.0 & 0.0 & 0.0\end{array}$




\begin{tabular}{|c|c|c|c|c|c|}
\hline Demographic Variables & Categories & Grower & Local Trader & Wholesaler & Retailer \\
\hline \multirow{6}{*}{$\begin{array}{l}\text { 3. Education level } \\
\text { (in percent) }\end{array}$} & Class 1-Class 5 & 17.0 & 39.5 & 19.5 & 27.0 \\
\hline & Class 6-Class 10 & 44.5 & 24.5 & 40.5 & 28.0 \\
\hline & SSC pass & 21.0 & 11.0 & 20.5 & 25.0 \\
\hline & HSC pass & 10.0 & 8.5 & 7.0 & 9.5 \\
\hline & $\begin{array}{l}\text { Honors/BA/BCom } \\
\text { /BSC/BSS pass }\end{array}$ & 7.0 & 2.0 & 2.0 & 2.0 \\
\hline & Illiterate & .5 & 14.5 & 10.5 & 8.5 \\
\hline \multirow{2}{*}{$\begin{array}{l}\text { 4. Source of Farm Workers (in } \\
\text { percent) }\end{array}$} & Number of workers & Grower & Local Trader & Wholesaler & Retailer \\
\hline & $1-5$ & 87.5 & 78.5 & 77.5 & 81.0 \\
\hline \multirow{4}{*}{ From Family members } & $6-10$ & 10.5 & 0 & 0 & 0 \\
\hline & $11-15$ & 1.0 & 0 & 0 & 0 \\
\hline & 15 and above & .5 & 0 & 0 & 0 \\
\hline & 0 & .5 & 21.5 & 22.0 & 19.0 \\
\hline \multirow[t]{6}{*}{ Employed from outside } & $1-5$ & 86.5 & 72.0 & 78 & 93.0 \\
\hline & $6-10$ & 1.5 & 5.5 & 1.0 & 6.5 \\
\hline & $11-15$ & 0 & 1.5 & 0 & .5 \\
\hline & 15 and above & 0 & 21.0 & 0 & 0 \\
\hline & 0 & 12.0 & 0 & 21.0 & 0 \\
\hline & Time duration & Grower & Local Trader & Wholesaler & Retailer \\
\hline \multirow{4}{*}{$\begin{array}{l}\text { 5. Duration of doing Flower } \\
\text { business (in percent) }\end{array}$} & less than 1 year & 1.0 & .5 & 1.0 & 1.0 \\
\hline & $1-5$ years & 3.5 & 4.0 & 15.0 & 22.5 \\
\hline & $5-10$ years & 22.5 & 21.5 & 25.0 & 25.0 \\
\hline & more than 10 years & 73.0 & 74.0 & 59.0 & 51.5 \\
\hline \multirow{3}{*}{$\begin{array}{l}\text { 6. Dealing with unsold flowers (in } \\
\text { percent) }\end{array}$} & Destroy the flowers & 100.00 & 100.00 & 100.00 & 75 \\
\hline & $\begin{array}{l}\text { Distribution at free } \\
\text { of cost }\end{array}$ & 0 & 0 & 0 & 3 \\
\hline & $\begin{array}{l}\text { Making of bouquet, } \\
\text { garland, basket etc. } \\
\text { to sell }\end{array}$ & 0 & 0 & 0 & 22 \\
\hline
\end{tabular}

Table: 1 Socio-economic data of respondents in different channel members $(n=220)$

Source: Field Survey, 2019

As flower business is labor-intensive, the scope for employment in this sector is very high. It has been observed in the study that 1 to 5 family members are found working in their farms. Majority $(87.5 \%)$ of them are involved in growing level followed by $81.0 \%$ in retailing, $78.5 \%$ in local trading, and $77.5 \%$ in wholesaling. Women are found mainly involved in plucking, sorting and packing flowers. It is also found that not only the family members are involved with the business. They also employ 1-5 workers from outside. More and more flower traders are now involved in growing and trading of flowers for long term. Most of the growers (73\%) and local traders (74\%) are found doing fresh flower business for more than 10 years. Moreover, none of them produces other crops in their lands like previous times except for 1 local trader who was found to produce jute instead of flowers in 2 bigha previously. Flowers are perishable in nature, and are damaged during harvesting, plucking, assembling, packing, loading and unloading for various reasons like delay in harvesting, pressing during wholesaling process, multiple handling and transportation. From the study it has been found that all the growers, local Traders and wholesalers destroy these unsold flowers. Although $75 \%$ retailers used to destroy the unsold flowers, $22 \%$ resale those in forms of bouquet, garland, basket etc. and the rest $3 \%$ of them distribute at free of cost.

\subsubsection{Marketing channels of the fresh flower trading in Bangladesh}

In fresh flower business of Bangladesh, many players deal in different levels of marketing channels which is known as Multichannel Marketing System. Here a single firm uses two or more 
marketing channels to reach one or more customer segments, lower channel cost, and increase more customized selling (Kotler \& Keller, 2014). From the field survey it has been found that, growers cultivate flowers in their fields throughout a season and harvest mature flowers early in the morning and place them in buckets of water to remove the field heat. Then while packing water is sprinkled to maintain high humidity. No specific standard is followed in grading flowers in the country rather it is merely based on size, color and defect. As a result, screening out quality flowers and maintaining standard pricing is often found to be difficult. It has been observed from the field survey that for distributing the flowers to final customer, they follow multichannel distribution system which comprises of six generic types of channels and this has been shown in figure 1. Here, in channel 1, growers deal directly to the local wholesale market or they may sell their flower to the middlemen like local traders who purchase the flowers from the field directly and after aggregating, packing and transporting flowers to local marketplace.

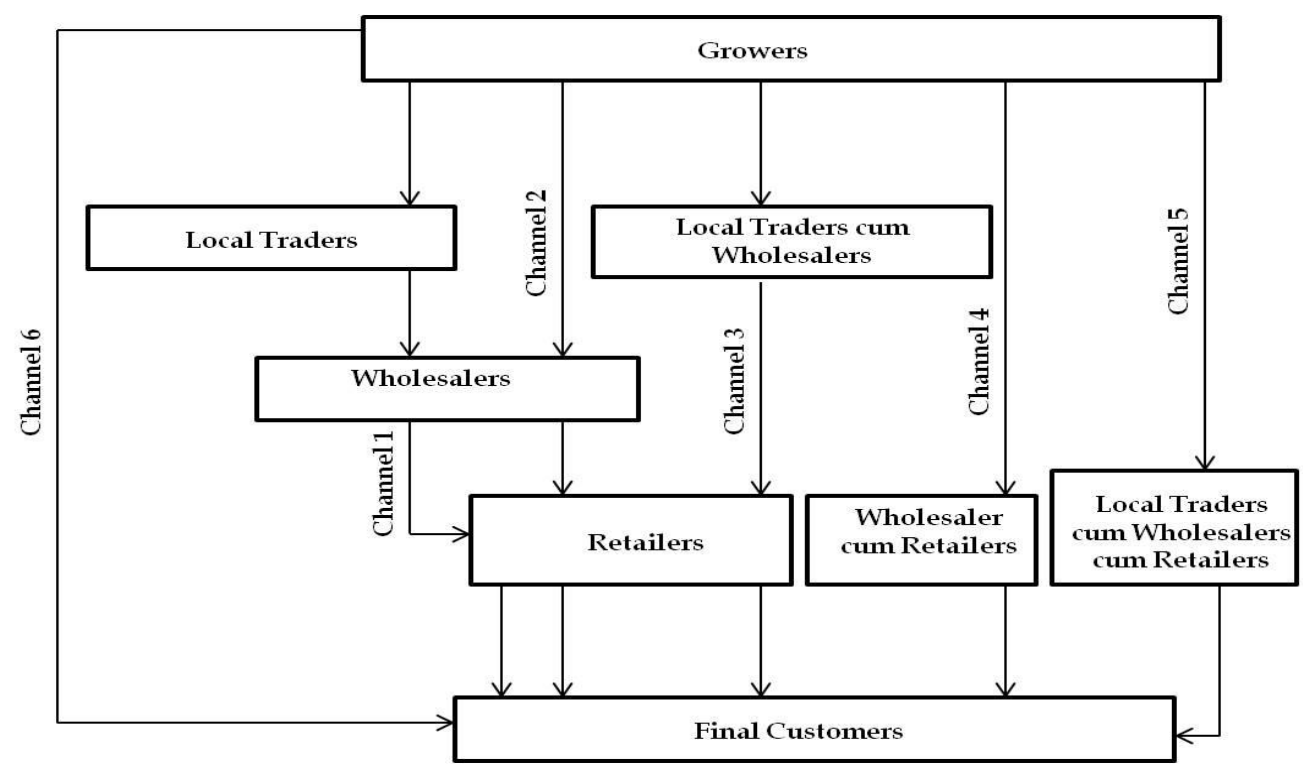

Fig 1: Marketing channels in flower business of Bangladesh, Source: Field Survey, 2019

Due to lack of permanent market place the growers sell their flowers in the field or in the wholesale market which deprives of getting better price. From the local wholesale market, packed flowers are sent to different wholesale markets situated in Dhaka and other parts of the country. Buying from there retailers bring to their retail shops, sort, and arrange those in different forms like flower bouquet, garland, baskets etc. for selling to final customers. In channel 2, growers have direct communication with the wholesalers who buy the produce directly from the field and bring those to the wholesale market for selling to retailers. In channel 3, growers communicate directly with some wholesalers who act as both local traders and wholesalers to buy the flowers directly from the field and bring those to the local wholesale market for selling to retailers. Sometimes growers sell their flowers directly to such a local trader who acts as wholesaler and retailer at a time. This makes the channel type 4. In channel 5, growers directly bring the flowers to the wholesale market and sell those to the wholesaler who is a local trader cum retailer as well. In channel 6, some final customers like event management firms or catering service organizations purchase directly from the growers at field or from the local wholesale market. Here they act as both the wholesaler and retailer. Here to mention, like most of the other agricultural commodities, the channel members also get larger portion of profit in flower business.

\subsection{Price disparity practiced by flower channel members}

From the field survey it has been found that the market price of flowers usually remains uncertain and unstable in Bangladesh which is mainly associated with its demand and supply in the market during different seasons. The price difference of different flowers during different seasons of 
the year is presented in table 2. It is observed from the research that in rainy season all the growers, local traders, wholesalers and retailers receive higher price by selling roses. However, the peak season of rose is the winter and the lean period is summer season and a transitional period is also observed in between the peak and lean periods. During the rainy season as production of rose decreases and postharvest loss is also occurred, consequently it makes the price higher due to low demand. But the demand of rose is more in both winter and spring due to increasing demand for celebrating festivals. In winter, growers sell a rose for BDT 3.53, and in rainy season BDT 4.50. A retailer also sells a rose at lower price of BDT 5.97 in winter season compared to BDT 8.50 in rainy season.

\begin{tabular}{|c|c|c|c|c|}
\hline \multirow[b]{2}{*}{ Flower traders } & \multicolumn{3}{|c|}{ a. Rose (BDT Per stick) } & \multirow[b]{2}{*}{ Rainy } \\
\hline & Winter & Spring & Summer & \\
\hline Growers & 3.53 & 3.17 & 3.48 & 4.50 \\
\hline Local Traders & 3.1 & 2.51 & 4.14 & 6.00 \\
\hline Wholesalers & 4.4 & 4.26 & 5.2 & 7.00 \\
\hline \multirow[t]{2}{*}{ Retailers } & 5.97 & 6.17 & 6.37 & 8.50 \\
\hline & \multicolumn{3}{|c|}{ b. Tuberose (BDT Per stick) } & \\
\hline Flower traders & Winter & Spring & Summer & Rainy \\
\hline Growers & 2.9 & 2.75 & 4.75 & 5 \\
\hline Local Traders & 4.15 & 4.02 & 6.50 & 6.76 \\
\hline Wholesalers & 5.16 & 5.1 & 7.80 & 8.80 \\
\hline \multirow[t]{2}{*}{ Retailers } & 6.31 & 6.88 & 10.00 & 11.00 \\
\hline & \multicolumn{3}{|c|}{ c. Marigold (BDT per mala) } & \\
\hline Flower traders & Winter & Spring & Summer & Rainy \\
\hline Growers & 8.09 & 3.88 & 3.60 & $4.77^{\circ}$ \\
\hline Local Traders & 10.69 & 8.1 & 3.45 & 5.71 \\
\hline Wholesalers & 8.73 & 8.73 & 6.3 & 7.75 \\
\hline \multirow[t]{2}{*}{ Retailers } & 15.99 & 15.92 & 13.81 & 14.72 \\
\hline & \multicolumn{3}{|c|}{ d. Gerbera (BDT Per stick) } & \\
\hline Flower traders & Winter & Spring & Summer & Rainy \\
\hline Growers & 12.0 & 10.45 & 14 & 18 \\
\hline Local Traders & 20.53 & 15.50 & 21 & 28 \\
\hline Wholesalers & 27.52 & 19.11 & 28 & 35 \\
\hline \multirow[t]{2}{*}{ Retailers } & 33.00 & 26.00 & 39 & 43 \\
\hline & \multicolumn{3}{|c|}{ e. Gladiolus (BDT Per stick } & \\
\hline Flower traders & Winter & Spring & Summer & Rainy \\
\hline Growers & 10 & 8 & 14 & 18 \\
\hline Local Traders & 18 & 12 & 19 & 23 \\
\hline Wholesalers & 22 & 18 & 24 & 29 \\
\hline \multirow[t]{2}{*}{ Retailers } & 30 & 23 & 35 & 38 \\
\hline & \multicolumn{3}{|c|}{ f. Jasmine (BDT per mala) } & \\
\hline Flower traders & Winter & Spring & Summer & Rainy \\
\hline Growers & 5.00 & 6.20 & 1.51 & 2.60 \\
\hline Local Traders & 9.00 & 8.00 & 6.00 & 5.50 \\
\hline Wholesalers & 12.56 & 12.18 & 10.00 & 9.00 \\
\hline Retailers & 28.00 & 30.00 & 12.00 & 10.50 \\
\hline
\end{tabular}

Table 2: Season wise price difference of selected flowers of the channel members (in BDT per stick), Source: Field Survey, 2019

By selling Tube Rose in different seasons, growers, local traders, wholesalers and retailers receive higher price in rainy season in contrast they receive lower price in winter due to higher production during favorable weather. And according to the law of demand and supply, in a market economy when supply is more than the demand the market price of any product decreases. The flower market is also run by this 
mechanism. Supply of tuberose remains high during the months of February and March, despite January experiences a comparatively low supply. Lowest supply of tuberose is in April, September and October. Therefore, all the growers, local traders, wholesalers and retailers receive lower price in winter as of BDT 2.90, BDT 4.15, BDT 5.16 and BDT 6.31 respectively but higher price in rainy season as of BDT 5.00 , BDT 6.76, BDT 8.80 and BDT 11.00 respectively. The data of price difference of marigold in different seasons indicates that growers sell marigold at higher price of BDT 8.09 in winter season, but at lower price of BDT 3.88 in spring and BDT 3.60 in the summer. On the other side, local traders receive lower price in summer season and higher prices in winter season. Wholesalers receive the same price BDT 8.73 in winter and spring and earn lowest in summer, BDT 6.30. This is because the pick season for supplying marigold is October to April. Hence, the lean season for supplying marigold starts from May and continues up to November. In rainy season, retailers receive the higher price of gerbera (BDT 43) but growers receive lower price (BDT 18). Moreover, Gerbera is sold at lower price by all the traders in spring. It is observed that the gladiolus is more expensive one of the lists. The data presented in the table indicates that growers sell Gladiolus at a higher price of BDT 18 in rainy season. Local traders, wholesaler and retailer receive lower price in spring season. In winter, the retailers receive BDT 30 whereas wholesalers receive BDT 22, the local trader receives BDT 18 and the grower receives BDT 10. So, the difference between the grower and retailer is BDT 20. Hence, in the spring season they receive lowest price than the other season. The channel members earn more profit by selling jasmine in the winter season. But the price becomes lower in summer and rainy season as more Jasmines are grown due to favorable weather.

\subsection{Profitability Analysis for different flowers in different channel members}

The present section analyzes how different growers and traders are affected by season because of the price differentials of flower. To identify the profitability of flower production, total revenue has been compared to the total cost which is composed of fixed and variable cost. The variable costs are the cost of using the variable inputs like labor, irrigation, fertilizer, seed and fixed cost are the interest on operating capital and land preparation cost. For channel members, other variable costs like transportation, assembling, storage, cleaning, sorting, and wastage are added also. Based on these costs season wise profitability from selling different types of flowers in different channel members has been analyzed in following section.

\begin{tabular}{|c|c|c|c|c|c|c|c|c|c|c|c|c|}
\hline \multirow[b]{3}{*}{ Rose } & \multicolumn{12}{|c|}{ (per hector cost for growers; BDT Per100 sticks for local traders, wholesalers and retailers) } \\
\hline & Winter & & & Spring & & & Summe & & & Rainy & & \\
\hline & $\begin{array}{l}\text { Total } \\
\text { Revenue }\end{array}$ & $\begin{array}{r}\text { Total } \\
\text { Cost }\end{array}$ & Profit & $\begin{array}{l}\text { Total } \\
\text { Revenue }\end{array}$ & Total Cost & Profit & $\begin{array}{l}\text { Total } \\
\text { Reven } \\
\text { ue }\end{array}$ & $\begin{array}{r}\text { Total } \\
\text { Cost }\end{array}$ & Profit & $\begin{array}{l}\text { Total } \\
\text { Revenue }\end{array}$ & $\begin{array}{r}\text { Total } \\
\text { Cost }\end{array}$ & Profit \\
\hline Growers & 810,000 & $\begin{array}{l}460,00 \\
0\end{array}$ & 450,000 & 850,000 & 400,000 & 450,000 & $\begin{array}{l}900,00 \\
0\end{array}$ & 500,000 & 400,000 & 950,000 & 650,000 & $\begin{array}{l}300,0 \\
00\end{array}$ \\
\hline Local Traders & 400 & 350 & 50 & 400 & 350 & 50 & 420 & 550 & 130 & 650 & 450 & 200 \\
\hline Wholesalers & 450 & 300 & 150 & 400 & 320 & 180 & 600 & 500 & 100 & 700 & 600 & 100 \\
\hline Retailers & 500 & 400 & 100 & 700 & 400 & 300 & 600 & 500 & 100 & 900 & 700 & 200 \\
\hline
\end{tabular}

Table 3: Profit of channel members by selling rose in different seasons, Source: Field Survey, 2019

It appears from the above table that by trading rose, growers and traders earn more profit in spring when the demand of rose is found higher than the supply for using decoration in many occasions like marriage, birthday, corporate programs, trade fairs or government programs. Moreover, in the Valentine's Day, the demand of rose is mostly sky-scraping compared to other days. Nevertheless, as both the production and quality of rose are uppermost in this season, these are bought at lower price, which consequently lessen the profit of traders. Although traders receive the maximum revenue in rainy season as the price is charged higher due to supply shortage, but they need to bear more wastage or post-harvest loss during this season which shrinks the profit.

It is evident from table 4 that by selling Tuberoses growers, wholesalers, and retailers receive additional profit in the summer when the demand is found higher than the supply but lower profit in winter season when the supply is found superior than the demand due to more production in favorable 
weather conditions. Conversely, local traders earn additional profit in winter season but a lesser amount of in summer season.

\begin{tabular}{|c|c|c|c|c|c|c|c|c|c|c|c|c|}
\hline \multirow[b]{3}{*}{ Tube rose } & & & \multicolumn{9}{|c|}{ (per hector cost for growers, BDT Per100 sticks for local traders, wholesalers and retailers) } & \multirow[b]{3}{*}{ Profit } \\
\hline & \multicolumn{2}{|l|}{ Winter } & & Spring & & & Summer & & & Rainy & & \\
\hline & $\begin{array}{l}\text { Total } \\
\text { Revenue }\end{array}$ & $\begin{array}{l}\text { Total } \\
\text { Cost }\end{array}$ & Profit & $\begin{array}{l}\text { Total } \\
\text { Revenu } \\
\mathrm{e}\end{array}$ & $\begin{array}{l}\text { Total } \\
\text { Cost }\end{array}$ & Profit & $\begin{array}{l}\text { Total } \\
\text { Revenu } \\
\mathrm{e}\end{array}$ & $\begin{array}{l}\text { Total } \\
\text { Cost }\end{array}$ & Profit & $\begin{array}{l}\text { Total } \\
\text { Revenu } \\
\text { e }\end{array}$ & $\begin{array}{l}\text { Total } \\
\text { Cost }\end{array}$ & \\
\hline Growers & 300,000 & 250,000 & 150000 & 300,000 & 250,000 & 150,000 & 390,000 & 300000 & 190,000 & 400,000 & 350000 & 150,000 \\
\hline $\begin{array}{l}\text { Local } \\
\text { Traders }\end{array}$ & 470 & 250 & 220 & 500 & 290 & 210 & 650 & 550 & 100 & 800 & 600 & 200 \\
\hline Wholesalers & 550 & 400 & 100 & 700 & 400 & 300 & 900 & 400 & 500 & 800 & 690 & 210 \\
\hline Retailers & 600 & 500 & 100 & 700 & 500 & 200 & 1,000 & 800 & 200 & 1,100 & 900 & 200 \\
\hline
\end{tabular}

Table 4: Profit of channel members by selling Tube rose in different seasons Source: Field Survey, 2019

From the table 5 it is clear that by selling Marigold, growers earn added profit in spring as the demand of the flower lovers hit the highest point for celebrating different events like Pahela Falgun (spring festival), Ekushey February (International Mother Language Day), Valentine's Day and monthlong Ekushey Book Fair in February. But they take home lesser profit in winter season because of additional production in favorable weather. Alternatively, local traders, wholesaler, and retailers earn more profit in winter season due to the towering demand of use in wedding ceremony which is typically held from October to January in the country but they earn a reduced amount of profit in summer season due to lesser supply in adverse weather.

\begin{tabular}{|c|c|c|c|c|c|c|c|c|c|c|c|c|}
\hline & Winter & & & Spring & & & Summer & & & Rainy & & \\
\hline Marigold & $\begin{array}{l}\text { Total } \\
\text { Revenue }\end{array}$ & $\begin{array}{c}\text { Total } \\
\text { Cost }\end{array}$ & Profit & $\begin{array}{l}\text { Total } \\
\text { Revenue }\end{array}$ & Total Cost & Profit & $\begin{array}{l}\text { Total } \\
\text { Revenue }\end{array}$ & $\begin{array}{l}\text { Total } \\
\text { Cost }\end{array}$ & Profit & $\begin{array}{l}\text { Total } \\
\text { Revenue }\end{array}$ & $\begin{array}{c}\text { Total } \\
\text { Cost }\end{array}$ & Profit \\
\hline Growers & 240,000 & 140,000 & 100,000 & 245,500 & 140,000 & 155,000 & 200,000 & 140,000 & 140,000 & 280,000 & 160,000 & 120,000 \\
\hline $\begin{array}{l}\text { Local } \\
\text { Traders }\end{array}$ & 1,050 & 309 & 750 & 850 & 320 & 530 & 630 & 350 & 320 & 750 & 320 & 420 \\
\hline Wholesalers & 1,000 & 320 & 780 & 900 & 300 & 600 & 700 & 320 & 380 & 750 & 300 & 450 \\
\hline Retailers & 1,500 & 600 & 1,100 & 1,500 & 830 & 670 & 1,300 & 630 & 670 & 1,800 & 800 & 1,000 \\
\hline
\end{tabular}

Table 5: Profit of channel members by selling Marigold in different seasons, Source: Field Survey, 2019

From the table 6 it is visible that by trading Gerbera, growers and local traders receive more yields in rainy season but growers earn fewer in summer due to increased cost of bearing post-harvest loss, local traders earn less in spring because of high demand as flowers have become integral part of the celebration of the Pahela Falgun (spring festival), Valentine's Day, and month-long Ekushey Book Fair in February. However, both wholesalers and retailers take home more in spring, but they receive comparatively less in summer and winter respectively.

\begin{tabular}{|c|c|c|c|c|c|c|c|c|c|c|c|c|}
\hline & \multirow{2}{*}{\multicolumn{12}{|c|}{$\begin{array}{c}\text { (per hector cost for growers, BDT Per100 sticks for local traders, wholesalers and retailers) } \\
\text { Spring }\end{array}$}} \\
\hline \multirow[b]{2}{*}{ Gerbera } & Winter & & & Spring & & & Summer & & & Rainy & & \\
\hline & $\begin{array}{l}\text { Total } \\
\text { Revenue }\end{array}$ & $\begin{array}{l}\text { Total } \\
\text { Cost }\end{array}$ & Profit & $\begin{array}{l}\text { Total } \\
\text { Revenu } \\
\mathrm{e}\end{array}$ & $\begin{array}{l}\text { Total } \\
\text { Cost }\end{array}$ & Profit & $\begin{array}{l}\text { Total } \\
\text { Revenue }\end{array}$ & $\begin{array}{l}\text { Total } \\
\text { Cost }\end{array}$ & Profit & $\begin{array}{l}\text { Total } \\
\text { Revenue }\end{array}$ & Total Cost & Profit \\
\hline Growers & $3,061,977$ & 659,133 & & $3,000,70$ & & $2,400,50$ & & 859,133 & $2,239,86$ & & 954,500 & 2,445 , \\
\hline & & & $2,402,844$ & 0 & 600,200 & 0 & $3,099,000$ & & 7 & $3,400,000$ & & 500 \\
\hline Local Traders & 2,053 & 1,200 & 853 & 1,550 & 1,008 & 538 & 2,100 & 1,488 & 612 & 2,800 & 1,808 & 992 \\
\hline Wholesalers & 2,752 & 2,050 & 702 & 2,600 & 1,550 & 1,150 & 2,800 & 2,190 & 610 & 3,500 & 2,860 & 640 \\
\hline Retailers & 3,300 & 2,760 & 540 & 3,600 & 1,990 & 2,510 & 3,900 & 2,860 & 1,040 & 4,300 & 3560 & 740 \\
\hline
\end{tabular}
2019

Table 6: Profit of channel members by selling Gerbera in different seasons, Source: Field Survey,

From the table 7 it is evident that by trading Gladiolus, growers receive higher profit during summer but lesser in winter due to elevated demand for celebrating wedding and cultural events. Channel members like local traders make additional profit in spring but lower profit in summer. Besides, 
wholesalers and retailers get more by selling at higher prices in rainy season but get a reduced amount of in spring as more flowers are supplied compared to demand. So, the profitability of Gladiolus is found to be diverse in the different seasons.

\begin{tabular}{|c|c|c|c|c|c|c|c|c|c|c|c|c|}
\hline & Winter & & & Spring & & & Summer & & & Rainy & & \\
\hline Gladiolus & $\begin{array}{l}\text { Total } \\
\text { Revenue }\end{array}$ & $\begin{array}{l}\text { Total } \\
\text { Cost }\end{array}$ & Profit & $\begin{array}{l}\text { Total } \\
\text { Revenu } \\
\mathrm{e}\end{array}$ & $\begin{array}{l}\text { Total } \\
\text { Cost }\end{array}$ & Profit & $\begin{array}{l}\text { Total } \\
\text { Revenue }\end{array}$ & $\begin{array}{l}\text { Total } \\
\text { Cost }\end{array}$ & Profit & $\begin{array}{l}\text { Total } \\
\text { Revenu } \\
\text { e }\end{array}$ & $\begin{array}{l}\text { Total } \\
\text { Cost }\end{array}$ & Profit \\
\hline Growers & 800,000 & 500,000 & 300,000 & 850,000 & 500,000 & 350,000 & 900,000 & 500,000 & 400,000 & $\begin{array}{l}950,00 \\
0\end{array}$ & 600,000 & 350,000 \\
\hline $\begin{array}{l}\text { Local } \\
\text { Traders }\end{array}$ & 1,800 & 1,000 & 800 & 2,000 & 900 & 1,100 & 2,000 & 1,400 & 600 & 2,400 & 1,800 & 600 \\
\hline Wholesalers & 2,200 & 1,900 & 300 & 2,000 & 1,800 & 200 & 2,500 & 1,900 & 600 & 3,000 & 2,300 & 700 \\
\hline Retailers & 3,000 & 2,300 & 700 & 2,300 & 2,400 & 100 & 3,500 & 2,430 & 960 & 4,000 & 3,000 & 1,000 \\
\hline
\end{tabular}

Table 7: Profit of channel members by selling Gladiolus in different seasons, Source: Field Survey, 2019

It is apparent from table 8 that by selling Jasmine, growers make more profit in rainy season through elevated production and a reduced amount of post-harvest loss, but local traders earn more profit in winter season when the demand is higher than the supply. On the contrary, growers and local traders receive not as much of in winter and summer respectively. Though the wholesalers earn similar profit throughout the seasons, retailers make added profit in spring and lesser profit in rainy season when the supply is found to be more than the demand. Retailers earn more profit than other channel members as we know that in every market, channel member in the last stage earn more than the others.

\begin{tabular}{|c|c|c|c|c|c|c|c|c|c|c|c|c|}
\hline & Winter & & & Spring & & & Summer & & & Rainy & & \\
\hline Jasmine & $\begin{array}{l}\text { Total } \\
\text { Revenue }\end{array}$ & $\begin{array}{l}\text { Total } \\
\text { Cost }\end{array}$ & Profit & $\begin{array}{l}\text { Total } \\
\text { Revenu } \\
\text { e }\end{array}$ & $\begin{array}{l}\text { Total } \\
\text { Cost }\end{array}$ & Profit & $\begin{array}{l}\text { Total } \\
\text { Revenue }\end{array}$ & $\begin{array}{l}\text { Total } \\
\text { Cost }\end{array}$ & Profit & $\begin{array}{l}\text { Total } \\
\text { Revenu } \\
\text { e }\end{array}$ & $\begin{array}{l}\text { Total } \\
\text { Cost }\end{array}$ & Profit \\
\hline Growers & 60,000 & 45,000 & 25,000 & 60,000 & 48,000 & 22,000 & 40,000 & 30,000 & 10,000 & 50,000 & 10,000 & 40,000 \\
\hline $\begin{array}{l}\text { Local } \\
\text { Traders }\end{array}$ & 900 & 400 & 500 & 800 & 430 & 470 & 600 & 200 & 300 & 700 & 400 & 300 \\
\hline $\begin{array}{l}\text { Wholesaler } \\
\text { s }\end{array}$ & 1,200 & 900 & 300 & 1,200 & 900 & 300 & 1,000 & 700 & 300 & 900 & 600 & 300 \\
\hline Retailers & 2,800 & 1,500 & 1,300 & 3,000 & 1,500 & 1,500 & 1,200 & 1,000 & 200 & 1,000 & 950 & 50 \\
\hline
\end{tabular}

Table 8: Profit of channel members by selling Jasmine in different seasons, Source: Field Survey, 2019

So, it is obvious from the study that, profits earned by different types of traders in fresh flower business are dissimilar in different seasons. In this way, in the flower industry, different traders are benefitted in different way.

\section{Discussions and Conclusions}

Although with the increased demand for flowers in Bangladesh there is ample opportunity for earning more profit from flower production, the price and profit of different flowers seasonally varies with the different channel members. Higher price is observed for Rose, Tuberose, Gerbera, and Gladiolus in rainy season due to additional cost of wastage or post-harvest loss, but the price is lower in spring because of favorable weather for production. On the contrary, by selling marigold they receive higher prices in winter season which is suitable for cultivating and harvesting marigold and lower price in summer. By trading Jasmine, they receive higher price in winter and lower in Rainy season. The study also finds that, by selling these flowers growers and traders are benefitted in a different way, earning varied profits in different seasons. Overall, market price is found uncertain and unstable which, in turn affects the profit of the grower, local trader, wholesaler and retailer. The authors also witnessed the seasonal disparity in profitability of different kinds of flowers. In favorable weather of a season, profit of flowers is found lower due to additional supply of flowers compared to the demand and in adverse weather of a season, extra cost of wastage or post-harvest loss also makes the profit lesser. As the price and profit are found varied with different seasons, Government and NGOs should help the farmers and traders to establish modern storage facility in wholesale market area; arrange special vehicles with air conditioning facility for transportation; initiate soft loan; organize training on modern harvesting and 
post-harvest management; and arrange the availability of quality planting materials, fertilizers, pesticides at reasonable cost in the industry. In addition, Government of Bangladesh should help eliminate unnecessary interventions of local leaders, law enforcing agencies like police, and different groups of toll collectors and should pay attention to the mass media campaign and arranging fairs and exhibitions that can add to the marketing opportunity of flower industry in the country.

Consistent with the research (Hossain et al., 2015) this study shows that price of flowers in Bangladesh varies as a result of seasonal effects. The study also explores the damage of flower trading or postharvest losses which corroborate the works of (Mou, 2012; Balamuruganet, 2014). But the study is different from others in flower business context where it has been showed that different seasons of a year affect the price and profit of different flowers in the country. A very few authors like Hossain et al. (2015) found the variability of market demand, supply and price of different genotypes of Gladiolus among different months of the year, special days of the year and even different days of the week in Bangladesh. This study contributes to the existing literature on flower business where the seasonal disparity is specifically studied in the context of flower trading in Bangladesh. Even though, several research studies on flower trading in Bangladesh have been done, this study is one of the first attempts to compare the price and profit differentials during different seasons. In this way, study provides insights on the factors that lead to price differences in flower business in the country.

Accordingly, the findings of this study can be used as valuable reference for developing an efficient flower market in Bangladesh that will subsequently contribute to the affordable flower trading system in the country where the price and demand from buyers should be assessed continuously. As this study is the first one that analyses the seasonal disparity on price spread of flower business in Bangladesh, it will therefore provide useful policy insights to the policy makers as well as researchers for reducing the seasonal effects on flower trading in Bangladesh. In this way this study will also help the government to realize the importance and develop ways of solving the effects of seasons on price and profitability with the channel members in Bangladesh.

\section{Limitations and Direction for Future research}

The flower is an important ornamental plant which gives high return to the growers as well as channel members, generates employment and can earn foreign exchange also. The present study investigates the variation in price and profitability of flower trading in Bangladesh. But like other studies, this study has some limitations also. Due to unavailability of data about the total number of flower growers and traders in the country, a smaller sample size through adopting convenient sampling method is considered for the study, which may affect the validity of findings to some extent. As only Dhaka division was selected purposively, future research should also assess the seasonal effects of price disparity on flower trading in other flower producing districts which could provide a wider representation of the fresh flower trading in Bangladesh. In the study selected flowers are considered which might not explore the total picture of the flower industry of the country. In addition, future research can use different methodologies like trend analysis to observe what will happen in the future. Finally, the study can be replicated in different countries to review whether the effects of seasons on price disparity and profitability of flower trading operate across diverse national markets as well.

\section{References}

Balamurugan, L.K., Jyothi, T. and Samudhra Rajkumar, C. (2014). Production, post-harvest handling and marketing of cut-flowers in Tamil Nadu, International Journal of Recent Scientific Research, 5(11), pp.2117-2122.

Bangladesh Bureau of Statistics (2016). Statistical Yearbook Bangladesh, Dhaka, Ministry of Planning, Government of the People's Republic of Bangladesh.

Bangladesh Bureau of Statistics (2017). Statistical Yearbook Bangladesh, Dhaka, Ministry of Planning, Government of the People's Republic of Bangladesh.

Bangladesh Bank, (2019). Exchange rate of Taka (online). Available at: http://www.bb.org.bd/econdata/exchangerate.php [Accessed 05 Feb. 2020].

Begum, M. (2015). Ornamental Flower: Local and Export Market of Bangladesh, Bangladesh Journal of Tariff and Trade, 1(2), pp 43-53.

Export Promotion Bureau, (2012). Bangladesh: Cut flower exports decline as domestic consumption rises, Export Promotion Bureau Database, 2016. 
Financial Express. (2019). Flower business in Jashore blooms in February, Financial Express, [online]. Available at: https://thefinancialexpress.com.bd [Accessed 13 Feb. 2019].

Griffen, M. (1995), Challenging the Tulip, Ceres. The FAO Review (FAO), 27,3, (May-June).

Haque, M.A., Miah, M.A.M, Hossain, S. and Alam, M., (2012). Economics of Marigold Cultivation in Some Selected Areas of Bangladesh. Bangladesh Journal of Agricultural, 37(4), pp. 711-720.

Haridas, S.K. (2010). Evaluating the Performance of Wayanad District Floriculture Society, MBA Project Report, Kerala Agricultural University, Trissur.

Hossain, M.D., Bhuiyan, M.S.R., Hossain, M.S., Paul, D.N.R. and Ullah, M.Z. (2015). Variation in Demand, Supply and Market Price of Different Genotypes of Gladiolus Flower Available in Bangladesh, Journal of Sylhet Agricultural University Bangladesh, 2(2), pp. 275-281.

Hossain, S.Z. (2019). Floriculture business showing robust growth, Dhaka Tribune, [online]. Available at: https://www.dhakatribune.com [Accessed 24 Feb. 2019].

Jahan, H. (2009). Production, post-harvest handling and marketing of cut-flowers in Bangladesh: An agribusiness study. SAARC Journal Agriculture, 7(2), pp.1-14.

Khan, A. (2013). Flower Market Development in Bangladesh. In: National Seminar on Floriculture Development in Bangladesh, Dhaka: Ministry of Agriculture, Available at: https://www.researchgate.net/publication [8 May.18].

Kotler, P. and Keller, K. (2014). Marketing Management, 15th Edition, Upper Saddle River: Prentice Hall, pp.425-426.

Laboni, S. A., Promy, J. A., Abdullah, S.Z. (2019). Export Potentiality of Flower Industry: A Case Study on Bangladeshi Flower Industry, North American Academic Research, 2(11), pp. 251-271.

Mohanan, A. (2015). Economic Analysis of Orchid Flower trade in Kerala, M.S. Thesis report, Department of Agricultural Economics, College of Agriculture, Vellayani, Thiruvananthapuram, Keral, India

Mohiuddin, M. (2016). Flower Business Flourish Floriculture: A Study on Bangladesh. International Journal of Business and Management Invention, 5(10), pp. 09-13.

Mou, N.H. (2012). Profitability of flower production and marketing system of Bangladesh. Bangladesh Journal of Agriculture Research, 37(1), pp. 77-95.

Omar, M.I., Chowdhury, M.M.I., Islam, M.T., Islam, M.R. and Islam, M. (2014). Marketing Efficiency and Post-Harvest Loss of Flower in Bangladesh. Journal of Business and Management, 16(1), pp. 45-51.

Raha, S. K. And Sultana, N. (1995), Marketing Flowers of Flowers in Dhaka City, Bangladesh, Bangladesh Journal of Agricultural Economics, 18(454-2016-36491), pp.43-50.

Raha, S.K. and Siddika, M. (2004). Price spreads in cut-flower marketing: Some evidence from Bangladesh. Bangladesh Journal of Agricultural Economics, 27(2), pp. 87-97.

Rakibuzzaman, M., Rahul, S., Jahan, M. R., Ifaz, M. I. and Uddin, A. J. (2018). Flower Industry in Bangladesh: Exploring Floriculture Potential. International Journal of Business Social and Scientific Research, 7(1), pp. 50-56.

Sangeetha, K. (2005). Marketing of commercial flowers-a study in Palakkad and Thrissur districts of Kerala, Doctoral Dissertation, Department of Rural Marketing Management, College of Cooperation Banking and Management, Vellanikkara.

Singh, S.B. and Punitha, P. (2012). Entrepreneurship Development through Anthrium Flower-A Case Study of Mizoram, North-East India, Indian Research Journal of Extension Education, 12(3), pp. 74-78.

Singh, R. D., Burark, S. S. and Meena, G. L. (2008). Marketing Behavior of Marigold Flower Cultivation in Jaipur District of Rajasthan, Indian Journal of Agricultural Economics, 63(3), pp. 383.

Steephan, L. (2011). Changing scenario of Cut Flower Industry in Central Kerala-An Economic Analysis, M. Sc (Ag) Thesis, Kerala Agricultural University, Trissur.

Wardad, Y. (2019). Lower business booms in country-output hits record 3.2 billion pieces last FY. The Financial Express [online]. Available at: https://thefinancialexpress.com.bd [Accessed 04 Feb. 2019].

Yeasmin, S. (2009). Socioeconomic Impact of Commercial Floriculture on Improving Livelihood of Farm Households in Selected Areas of Jessore District. M.S. Thesis, Department of Agricultural Economics, Bangladesh Agricultural University, Mymensingh, Bangladesh. 